\title{
URINARY EXCRETION OF FORMIMINOGLUTAMIC ACID BY HUMAN SUBJECTS AFTER ANTIFOLIC ACID THERAPY ${ }^{1}$
}

\author{
By HOWARD H. HIATT, MADELINE GOLDSTEIN, AND HERBERT TABOR \\ (From the Departments of Medicine, Harvard Medical School and Beth Israel Hospital, Boston, \\ Mass., and the National Institute of Arthritis and Metabolic Diseases, National \\ Institutes of Health, Bethesda, Md.)
}

(Submitted for publication December 9, 1957; accepted February 6, 1958)

In the accompanying paper a sensitive and specific enzymatic method is described for the measurement of formiminoglutamic acid (1). In this paper data are presented on the application of this method for the assay of formiminoglutamic acid in the urine of a variety of patients.

Formiminoglutamic acid is an intermediate in histidine metabolism, and requires tetrahydrofolic acid for its further metabolism. Previous results (2-5) have demonstrated that the urinary excretion of this compound is markedly increased in folic acid-deficient rats. Formiminoglutamic acid has also been reported $(6,7)$ in the urine of several patients receiving folic acid antagonists, although the techniques available for these studies were relatively cumbersome and inaccurate.

Using the enzymatic procedure for the assay of formiminoglutamic acid, we have found that small amounts of this compound can often be detected in the urine of adults and children. A marked elevation in formiminoglutamic acid excretion was noted after amethopterin (methotrexate) therapy in children with acute leukemia.

\section{METHODS}

Timed urine samples were obtained from 3 healthy adults and from 20 patients on the Medical and Pediatric Services of the Beth Israel Hospital. In addition, specimens were obtained from 22 children undergoing therapy for acute leukemia at the Children's Cancer Research Foundation. Sixteen of the latter group were receiving the antifolic acid drug, amethopterin, in the amounts listed in Table III. Pertinent clinical data are summarized in Tables I to III.

Urine samples were refrigerated immediately, and either analyzed for formiminoglutamic acid within 18 hours or frozen within that time and kept at $-10^{\circ} \mathrm{C}$. until the analyses were performed. Urinary formiminoglutamic acid was measured by the procedure of Tabor and Wyngarden (1). Most urine samples containing

1 This work was supported in part by grants from the Jane Coffin Childs Memorial Fund for Medical Research and the National Cancer Institute (C-3151). large quantities of formiminoglutamic acid were subjected to the alkaline hydrolysis procedure described in the accompanying paper (1). In all instances there was a 95 to 100 per cent disappearance of the material reacting in the formiminoglutamic acid test.

\section{RESULTS}

Urinary excretion of formiminoglutamic acid in the nonleukemic children and adults varied from 0 to 0.51 micromole per hour (Table I).

The children with acute leukemia who had not received amethopterin for at least one week prior to the study excreted 0 to 1.18 micromoles of formiminoglutamic acid per hour (Table II). The three children in this group who had never been given the drug excreted 0 to 0.03 micromole per hour. Sixteen patients receiving amethopterin excreted quantities of formiminoglutamic acid in excess of 1.27 micromoles per hour; the excretion exceeded 8 micromoles in 11 of these cases (Table III). A rise in formiminoglutamic acid excretion was not apparent until after several weeks of amethopterin therapy, and often not until long after the patient had experienced a remission. Thus, Patient 33 excreted 0.59 micromole per hour 12 weeks following the institution of treatment, and 60 micromoles after 18 weeks; in Patients 26, 43 and 44 a similar phenomenon was observed. Following the cessation of therapy, Patients 34,47 and 55 showed a sharp fall in formiminoglutamic acid excretion. The quantity of formiminoglutamic acid in the urine has no apparent relationship to the response of the leukemic process to therapy.

No evidence was found in any of the urines for any substances that would interfere with the formiminoglutamic acid assay. This was demonstrated by recovery experiments in which the urine samples were assayed after the addition of known increments of formiminoglutamic acid; 95 to 100 per cent recovery was obtained in all cases tested. 
TABLE I

Excretion of formiminoglutamic acid in nonleukemic subjects

\begin{tabular}{|c|c|c|c|c|}
\hline Subject & Sex & Age & Clinical data & $\begin{array}{l}\text { Urinary } \\
\text { formimino- } \\
\text { glutamic } \\
\text { acid } \\
\text { M/h. }\end{array}$ \\
\hline \multicolumn{5}{|l|}{ Children } \\
\hline $\begin{array}{l}2 \\
5 \\
8\end{array}$ & $\begin{array}{l}\mathbf{M} \\
\mathbf{M} \\
\mathbf{F}\end{array}$ & $\begin{array}{l}12 \\
10 \\
10\end{array}$ & $\begin{array}{l}\text { Ulcerative colitis } \\
\text { Streptococcal pharyngitis } \\
\text { Repair of uretero-pelvic } \\
\text { junction }\end{array}$ & $\begin{array}{l}0.18 \\
0.21 \\
0\end{array}$ \\
\hline $\begin{array}{l}45 \\
46 \\
89 \\
90\end{array}$ & $\begin{array}{l}\mathbf{M} \\
\mathbf{M} \\
\mathbf{M} \\
\mathbf{F}\end{array}$ & $\begin{array}{r}11 \\
2 \\
15 \\
10\end{array}$ & $\begin{array}{l}\text { Rhabdomyosarcoma } \\
\text { Neuroblastoma } \\
\text { Torsion of testicle } \\
\text { Fracture of fibula }\end{array}$ & $\begin{array}{l}0.22 \\
0 \\
0 \\
0.39\end{array}$ \\
\hline \multicolumn{5}{|l|}{ Adults } \\
\hline $\begin{array}{l}60 \\
61 \\
62 \\
82 \\
83 \\
84 \\
85 \\
86 \\
87 \\
88 \\
91\end{array}$ & $\begin{array}{l}\mathbf{M} \\
\mathbf{M} \\
\mathbf{M} \\
\mathbf{M} \\
\mathbf{M} \\
\mathbf{M} \\
\mathbf{M} \\
\mathbf{M} \\
\mathbf{M} \\
\mathbf{M} \\
\mathbf{F}\end{array}$ & $\begin{array}{l}32 \\
35 \\
29 \\
65 \\
65 \\
60 \\
59 \\
67 \\
19 \\
68 \\
72\end{array}$ & $\begin{array}{l}\text { Normal control } \\
\text { Normal control } \\
\text { Normal control } \\
\text { Arteriosclerotic heart disease } \\
\text { Metastatic carcinoma } \\
\text { ? Neurologic disease } \\
\text { Angina pectoris } \\
\text { Emphysema } \\
\text { Idiopathic thrombocytopenia } \\
\text { Pneumonia } \\
\text { Aortic stenosis, angina } \\
\text { pectoris }\end{array}$ & $\begin{array}{l}0.40 \\
0 \\
0.50 \\
0.19 \\
0.13 \\
0.51 \\
0.25 \\
0 \\
0.13 \\
0.31 \\
0.03\end{array}$ \\
\hline $\begin{array}{l}92 \\
93 \\
94 \\
95 \\
96\end{array}$ & $\begin{array}{l}\mathbf{F} \\
\mathbf{F} \\
\mathbf{F} \\
\mathbf{F}\end{array}$ & $\begin{array}{l}68 \\
64 \\
64 \\
70 \\
60\end{array}$ & $\begin{array}{l}\text { Acute myocardial infarct } \\
\text { Acute myocardial infarct } \\
\text { Congestive heart failure } \\
\text { Angiocystic hamartoma } \\
\text { Acute myocardial infarct }\end{array}$ & $\begin{array}{l}0.23 \\
0.35 \\
0.09 \\
0.07 \\
0.08\end{array}$ \\
\hline
\end{tabular}

\section{DISCUSSION}

The data presented above demonstrate the suitability of the assay procedure for the determination of urinary formiminoglutamic acid excretion. Pre- liminary data are presented on the excretion of this compound in a variety of cases, demonstrating that it is frequently detected in the urine of children and adults. The most striking results are represented by the increased excretion of formiminoglutamic acid in leukemic children during amethopterin treatment. The increased excretion in the amethopterin-treated cases is presumably due to the interference of the amethopterin with the formation of tetrahydrofolic acid (8), a compound required for the further metabolism of formiminoglutamic acid.

The increased excretion was often not seen until after several weeks or months of therapy. It should be noted that the quantity of amethopterin given was relatively small, so as to avoid toxicity. It is of considerable interest that in several patients a complete remission of the leukemia had taken place well in advance of an increase in formiminoglutamic acid excretion, or in formic acid excretion (9). If the increase in urinary formiminoglutamic acid and formic acid can be considered an index of folic acid deficiency (2-5), these observations may provide in vivo support for the thesis that leukemic cells have a greatly increased sensitivity to folic acid deprivation (10).

\section{SUM MARY}

An enzymatic procedure has been applied to the assay of formiminoglutamic acid in the urine of adults and children with a variety of disease states. Urinary formiminoglutamic acid was fre-

TABLE II

Formiminoglutamic acid excretion in children with acute leukemia not receiving amethopterin

\begin{tabular}{|c|c|c|c|c|c|}
\hline Subject & $\operatorname{Sex}$ & Age & Clinical data & $\begin{array}{l}\text { Previous } \\
\text { amethopterin } \\
\text { and interval } \\
\text { since last given }\end{array}$ & $\begin{array}{c}\text { Urinary } \\
\text { formimino- } \\
\text { glutamic acid } \\
\boldsymbol{\mu M / h r} .\end{array}$ \\
\hline 21 & $\mathbf{M}$ & 13 & In remission on $50 \mathrm{mg}$. of 6-mercapto- & Yes; 5 months & $\mathbf{0}$ \\
\hline 23 & $\mathbf{M}$ & 4 & In relapse; receiving adrenal steroids, & Yes; 6 months & 0 \\
\hline 24 & $\mathbf{M}$ & 6 & $\begin{array}{l}\text { In relapse; receiving intravenous adre- } \\
\text { nocorticotrophic hormone, chloram- } \\
\text { phenicol, and novobiocin }\end{array}$ & Yes; 5 months & 1.01 \\
\hline 26 & $\mathbf{M}$ & 3 & $\begin{array}{l}\text { No previous therapy; receiving adrenal } \\
\text { steroids }\end{array}$ & No & $\mathbf{0}$ \\
\hline 40 & $\mathbf{F}$ & 7 & $\begin{array}{l}\text { Amethopterin omitted } 14 \text { days previ- } \\
\text { ously because of severe toxicity (sto- } \\
\text { matitis); partial remission }\end{array}$ & Yes; 14 days & 1.18 \\
\hline 40 & $\mathbf{F}$ & 7 & $\begin{array}{l}\text { Amethopterin omitted } 23 \text { days previ- } \\
\text { ously }\end{array}$ & Yes; 23 days & 0.42 \\
\hline $\begin{array}{l}\mathbf{5 0} \\
\mathbf{5 3}\end{array}$ & $\mathbf{M}$ & $\begin{array}{l}1 \\
2\end{array}$ & $\begin{array}{l}\text { No previous therapy } \\
\text { No previous therapy }\end{array}$ & $\begin{array}{l}\text { No } \\
\text { No }\end{array}$ & $\begin{array}{c}0.03 \\
0\end{array}$ \\
\hline
\end{tabular}


TABLE III

Formiminoglutamic acid excretion in subjects with acute leukemia undergoing treatment with amethopterin

\begin{tabular}{|c|c|c|c|c|c|c|}
\hline Patient & Sex & Age & Remission & Dosage of amethopterin & $\begin{array}{c}\text { Duration of } \\
\text { treatment }\end{array}$ & $\begin{array}{l}\text { Urinary } \\
\text { formimino- } \\
\text { glutamic } \\
\text { acid } \\
\mu M / h \text { r. }\end{array}$ \\
\hline $\begin{array}{l}26 \\
26\end{array}$ & $\begin{array}{l}\mathbf{M} \\
\mathbf{M}\end{array}$ & $\begin{array}{l}3 \\
3\end{array}$ & $\begin{array}{l}\text { Yes } \\
\text { Yes }\end{array}$ & $\begin{array}{l}1.25 \mathrm{mg} \text {. daily } \\
1.25 \mathrm{mg} \text {. daily }\end{array}$ & $\begin{array}{l}4 \text { weeks } \\
10 \text { weeks }\end{array}$ & $\begin{array}{l}0.06 \\
8.8\end{array}$ \\
\hline 27 & $\mathbf{F}$ & 5 & Yes & $1.25 \mathrm{mg}$. daily & 3 months & 1.3 \\
\hline $\begin{array}{l}28 \\
28\end{array}$ & $\begin{array}{l}\mathbf{M} \\
\mathbf{M}\end{array}$ & $\begin{array}{l}4 \\
4\end{array}$ & $\begin{array}{l}\text { Yes } \\
\text { Yes }\end{array}$ & $\begin{array}{l}2.5 \mathrm{mg} \text {. daily } \\
2.5 \mathrm{mg} \text {. daily }\end{array}$ & $\begin{array}{l}6 \text { weeks } \\
18 \text { weeks }\end{array}$ & $\begin{array}{l}11.0 \\
11.2\end{array}$ \\
\hline 29 & $\mathbf{F}$ & 4 & Yes & 1.25 mg. daily & 11 months & 2.8 \\
\hline 30 & $\mathbf{M}$ & 4 & No & $1.25 \mathrm{mg}$. daily (and prednisone) & 1 year & 9.3 \\
\hline $\begin{array}{l}33 \\
33 \\
33 \\
33 \\
33 \\
33\end{array}$ & $\begin{array}{l}\mathbf{M} \\
\mathbf{M} \\
\mathbf{M} \\
\mathbf{M} \\
\mathbf{M} \\
\mathbf{M}\end{array}$ & $\begin{array}{l}8 \\
8 \\
8 \\
8 \\
8 \\
8\end{array}$ & $\begin{array}{l}\text { Yes } \\
\text { Yes } \\
\text { Yes } \\
\text { Yes } \\
\text { Yes } \\
\text { Yes }\end{array}$ & $\begin{array}{l}2.5 \mathrm{mg} \text {. daily (and prednisone) } \\
2.5 \mathrm{mg} \text {. daily (and prednisone) } \\
2.5 \mathrm{mg} \text {. daily (and prednisone) } \\
2.5 \mathrm{mg} \text {. daily (and prednisone) } \\
2.5 \mathrm{mg} \text {. daily (and prednisone) } \\
2.5 \mathrm{mg} \text {. daily (and prednisone) }\end{array}$ & $\begin{array}{l}3 \text { weeks } \\
4 \text { weeks } \\
10 \text { weeks } \\
12 \text { weeks } \\
15 \text { weeks } \\
18 \text { weeks }\end{array}$ & $\begin{array}{l}0.17 \\
0 \\
0.68 \\
0.59 \\
5.0 \\
60.0\end{array}$ \\
\hline $\begin{array}{l}34 \\
34 \\
34\end{array}$ & $\begin{array}{l}\mathbf{M} \\
\mathbf{M} \\
\mathbf{M}\end{array}$ & $\begin{array}{l}3 \\
3 \\
3\end{array}$ & Partial & $\begin{array}{l}1.25 \mathrm{mg} \text {. daily } \\
\text { Amethopterin stopped } 3 \text { weeks previously } \\
\text { Amethopterin stopped } 4 \text { weeks previously }\end{array}$ & 3 months & $\begin{array}{l}54.6 * \dagger \\
0.67 \\
1.6\end{array}$ \\
\hline $\begin{array}{l}35 \\
35\end{array}$ & $\begin{array}{l}\mathbf{M} \\
\mathbf{M}\end{array}$ & $\begin{array}{l}3 \\
3\end{array}$ & $\begin{array}{l}\text { Yes } \\
\text { Yes }\end{array}$ & $\begin{array}{l}2.5 \mathrm{mg} \text {. daily } \\
2.5 \mathrm{mg} \text {. daily }\end{array}$ & $\begin{array}{l}6 \text { months } \\
8 \text { months }\end{array}$ & $\begin{array}{l}60.9 \\
18.0\end{array}$ \\
\hline 37 & $\mathbf{F}$ & 7 & No & $2.5 \mathrm{mg}$. daily (and prednisone) & 2 months & 2.4 \\
\hline 41 & $\mathbf{F}$ & 8 & Yes & $2.5 \mathrm{mg}$. daily (and prednisone) & 3 months & 6.9 \\
\hline $\begin{array}{l}43 \\
43 \\
43\end{array}$ & $\begin{array}{l}\mathbf{M} \\
\mathbf{M} \\
\mathbf{M}\end{array}$ & $\begin{array}{l}9 \\
9 \\
9\end{array}$ & $\begin{array}{l}\text { Yes } \\
\text { Yes } \\
\text { Yes }\end{array}$ & $\begin{array}{l}2.5 \mathrm{mg} \text {. daily (and prednisone) } \\
2.5 \mathrm{mg} \text {. daily (and prednisone) } \\
2.5 \mathrm{mg} \text {. daily (and prednisone) }\end{array}$ & $\begin{array}{l}3 \text { weeks } \\
12 \text { weeks } \\
16 \text { weeks }\end{array}$ & $\begin{array}{l}0.18 \\
26.9 \\
42.9^{*}\end{array}$ \\
\hline $\begin{array}{l}44 \\
44 \\
44\end{array}$ & $\begin{array}{l}F \\
F \\
F\end{array}$ & $\begin{array}{l}5 \\
5 \\
5\end{array}$ & $\begin{array}{l}\text { Yes } \\
\text { Yes } \\
\text { Yes }\end{array}$ & $\begin{array}{l}1.5 \mathrm{mg} \text {. daily } \\
1.5 \mathrm{mg} \text {. daily } \\
1.5 \mathrm{mg} \text {. daily }\end{array}$ & $\begin{array}{l}6 \text { weeks } \\
15 \text { weeks } \\
22 \text { weeks }\end{array}$ & $\begin{array}{l}0.11 \\
2.5 \\
78.0\end{array}$ \\
\hline $\begin{array}{l}47 \\
47 \\
47 \\
47\end{array}$ & $\begin{array}{l}\mathbf{M} \\
\mathbf{M} \\
\mathbf{M} \\
\mathbf{M}\end{array}$ & $\begin{array}{l}3 \\
3 \\
3 \\
3\end{array}$ & $\begin{array}{l}\text { Early relapse } \\
\text { Early relapse } \\
\text { Early relapse } \\
\text { Early relapse }\end{array}$ & $\begin{array}{l}2.5 \mathrm{mg} \text {. daily } \\
2.5 \mathrm{mg} . \text { daily } \\
\text { Amethopterin stopped } 2 \text { weeks previously } \\
\text { Amethopterin stopped } 3 \text { weeks previously }\end{array}$ & $\begin{array}{l}5 \text { months } \\
5 \frac{1}{2} \text { months }\end{array}$ & $\begin{array}{l}9.3 \\
62.5 \\
5.6 \\
0\end{array}$ \\
\hline $\begin{array}{l}55 \\
55\end{array}$ & $\begin{array}{l}\mathbf{M} \\
\mathbf{M}\end{array}$ & $\begin{array}{l}3 \\
3\end{array}$ & $\begin{array}{l}\text { In relapse } \\
\text { In relapse }\end{array}$ & $\begin{array}{l}2.5 \mathrm{mg} \text {. daily } \\
\text { Amethopterin stopped } 3 \text { weeks previously }\end{array}$ & 8 months & $\begin{array}{l}96.1 \\
0.62\end{array}$ \\
\hline 56 & $\mathbf{M}$ & 6 & $\begin{array}{l}\text { Not yet } \\
\text { complete } \\
\text { (improving) }\end{array}$ & $2.5 \mathrm{mg}$. daily & 14 days & 3.2 \\
\hline 57 & $\mathbf{M}$ & 10 & Yes & $\begin{array}{l}2.5 \text { and } 5.0 \mathrm{mg} \text {. on alternate } \\
\text { days }\end{array}$ & 1 month & 9.9 \\
\hline
\end{tabular}

* Further evidence for the excretion of formiminoglutamic acid by these cases was obtained by paper chromatography in $t$-butanol 70, formic acid 15, water 15 , as described in the accompanying paper (1).

† During a 6 day period of hospitalization while this patient was receiving amethopterin therapy, 14 urine samples, excreted during known intervals, were collected. Formiminoglutamic acid excretion varied from 0.78 to 8.2 micromoles per $\mathrm{ml}$., and from 24 to 130 micromoles per hour.

quently detected in small quantities, and was markedly increased in children treated with the folic acid antagonist, amethopterin.

\section{ACKNOWLEDGMENTS}

The authors are most grateful to Dr. Sidney Farber and Dr. Rudolf Toch of the Children's Cancer Research
Foundation, who permitted us to study the children with acute leukemia.

\section{REFERENCES}

1. Tabor, H., and Wyngarden, L. A method for the determination of formiminoglutamic acid in the urine. J. clin. Invest. 1958, 37, 824. 
2. Bakerman, H. A., Silverman, M., and Daft, F. S. Influence of succinylsulfathiazole and folic acid on glutamic acid excretion. J. biol. Chem. 1951, 188, 117.

3. Silverman, M., Gardiner, R. C., and Bakerman, H. A. The nature of the glutamic acid excreted in folic acid deficiency. J. biol. Chem. 1952, 194, 815.

4. Tabor, H., Silverman, M., Mehler, A. H., Daft, F. S., and Bauer, H. L-Histidine conversion to a urinary glutamic acid derivative in folic-deficient rats. J. Amer. chem. Soc. 1953, 75, 756.

5. Rabinowitz, J., and Tabor, $H$. The urinary excretion of formic acid and formiminoglutamic acid in folic acid deficiency. J. biol. Chem. 1958, 230, 000.

6. Broquist, H. P. Evidence for the excretion of formiminoglutamic acid following folic acid antago- nist therapy in acute leukemia. J. Amer. chem. Soc. 1956, 78, 6205.

7. Luhby, A. L. Observations on the excretion of formiminoglutamic acid in folic acid deficiency in man. Clin. Res. Proc. 1957, 5, 8.

8. Futterman, S. Enzymatic reduction of folic acid and dihydrofolic acid to tetrahydrofolic acid. J. biol. Chem. 1957, 228, 1031.

9. Hiatt, H. H., Rabinowitz, J. C., Toch, R., and Goldstein, $M$. The effects of folic acid antagonist therapy on the urinary excretion of formic acid. Proc. Soc. exp. Biol. (N. Y.). In press.

10. Fischer, G. A., and Welch, A. D. Effect of citrovorum factor and peptones on mouse leukemia cells L-5178 in tissue culture. Science 1957, 126, 1018. 